by

PETER H. JUVILER

Paper No. 306

(1984)

A graduate of Yale, Peter Henry Juviler received his Ph.D. in Public Law and Government from Columbia University in 1960. Professor of Political Science at Barnard College, he is an Associate of the W. Averell Harriman Institute for Advanced Study of the Soviet Union. He has visited the USSR ten times since 1955, including two exchange visits totalling three semesters at the Moscow University Faculty of Law. A frequent contributor to journals and symposia on the USSR, he is author of Revolutionary Law and Order: Politics and Social Change in the USSR, and co-editor and contributor, Soviet Policy-Making: Studies of Communism in Transition.

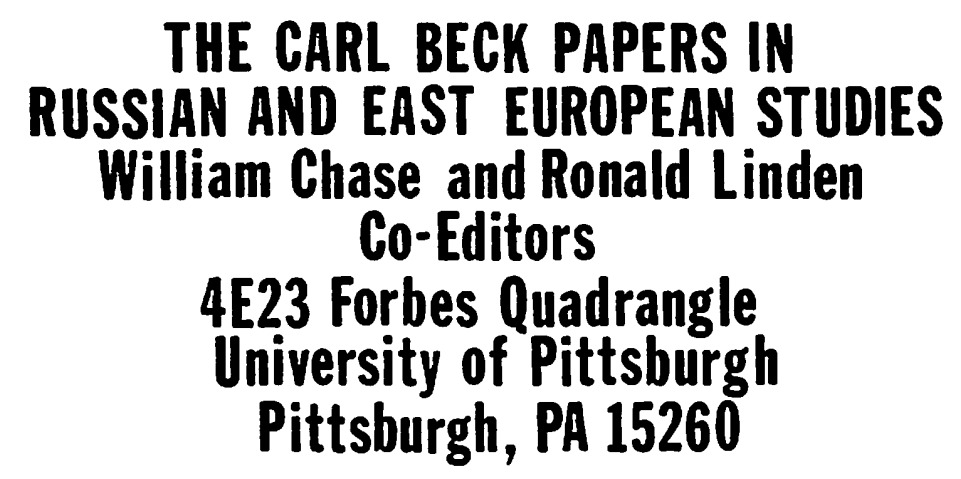




\section{THE FAMILY IN THE SOVIET SYSTEM}

The Soviet Government* after Khrushchev has confronted crucial issues of reform in family law and family-oriented demographic policy. The central question of policy has been how "to harmonize the interests of society" in a more stable and fertile family than now exists, with "the interests of the family" in freer marital and reproductive choice. ${ }^{1}$

Govermmental approaches to reform support the conclusion, elaborated later, that family-government relations have changed significantly since Stalin's day. The relationship involves less governmental fiat and compulsion than in Stalin's time in promoting family stability and fertility. There is now more consultation with experts on family matters, much more searching debate before decisions are made, and apparently more realization of the complexity of socio-econamic issues in the USSR and of the limitations on governmental power to get its own way. If legal intervention has increased since Stalin, it is in the sphere of husbands' and fathers' material obligations to wives and children, in rules on the validity of marriage, and in "the struggle against religious survivals" in the family.

The Indispensable Family:

Had any of the various soviet projects for communalizing family roles and upbringing materialized; there would be no issues of family reform. But Stalin silenced the visionaries; Khrushchev refuted them; Brezhnev ignored what was left of them. ${ }^{2}$ Engels' image of socialist marriage as a "private

\footnotetext{
*"Govermment" here means the cluster of top Soviet officials who make and implement policy: members of the Politburo and Secretariat of the C.P.S.U., and other leading officials in state and party organizations.
} 
affair" has received a new Soviet interpretation to fit the family's vital role in the USSR as economic, emotional and above all demographic replenisher. ${ }^{3}$

Boris Urlanis; a leading demographer of his time, wrote that: "No social institution can serve the child as a substitute for maternal affection" which "the American public figure Dr. B. Spock" says "is as important for the emotional development of a human being as milk is for its physical development."4 The sociologist Kharchev has asserted that no institutional care, however conscientious, can substitute for the self-sacrificing love and the emotional closeness of parents. ${ }^{5}$ The abandonment of a child at birth by its mother; even though she be ummarried and fully entitled by law to hand the child over for a state upbringing, is depicted in the soviet press not as a golden opportunity for the public upbringing of one more paragon of communist virtue but as a shocking example of feckless indifference.

Thus, in one long Pravda article on mothers' rejection of their babies, a young, unmarried college student is depicted whose own mother; and former lover, want no part of any responsibility for her newborn child. The new mother is described as turning away to the wall when the nurse brings her baby for its first feeding: "I won't. Take him away. I don't want him!" Another mother nursed the rejected infant. It will eventually be adopted or raised in a state home. Moreover the mother has no legal obligation to raise it. But, according to Pravda's strongly disapproving report; the incident caused an understandable stir throughout the maternity home: "What!? A mother reject her own baby? But why? And who is this heartless woman; unworthy of the sacred title of mother?" 6

Forty years of Soviet comitment to "strengthening the family" culminated in the first constitutional references to it. Article 53 of the 1977 USSR 
Constitution signals the govermment's concern with its role in regulating marriage and providing family assistance:

Article 53. The Family is under the the protection of the state. Marriage is based on the voluntary agreement of a woman and a man; spouses are fully equal in family relations. The state manifests concern for the family through its creation and expansion of an extensive system of child care institutions, and by organizing and improving everyday services and public catering, paying childbirth allowances, awarding allowances and privileges to large families; and also by other forms of allowances and help to the family.

Article 66 of the 1977 USSR Constitution notes the mutual obligation of of parents and children; which the government supplements with its own institutions and assistance; but which it has been unwilling and unable to replace.

Article 66. USSR Citizens are obligated to care for the upbringing of their children; to prepare them for socially useful work, to raise worthy members of socialist society. Childrern are obligated to care for their parents and to help them.

These articles; it should be noted, reappear in the constitutions of each of the fifteen union republics. 7

Enshrined at the highest level of state symbolism, Articles 53 and 66 symbolize the government's concern with the family's demographic functions and with the nature of their marital foundation. The concrete manifestation of this concern in operative law and policy and their implications for government-family relations in the USSR are the subject of this paper.

Family Law Reform:

As long as the family is entrusted with raising children; whatever may happen to its other roles such as material support; that alone creates a "social interest" in the USSR; 8 no less than in other countries; in the 
regulation of relations between the sexes and the regulation of family planning.

Soon after Stalin died, the lifting of penalties on women in 1954 for having non-therapeutic abortions; and on doctors in 1955 for performing them (if in approved clinics); increased the freedom of reproductive choice in family planning; even if the changes did leave much to be desired in abortion procedures and the availability of contraceptives. ${ }^{9}$ This repeal of the 1936 ban on abortions resolved some of the issues of family planning but left burning issues of how to regulate relations between the sexes. When Khrushchev fell in 1964 these issues remained unresolved despite ten years of debate and the drafting of innumerable versions of a family law reform bill.

Particularly at issue were two provisions of the Stalinist edict of July 8, 1944. The first controversial provision of that edict eliminated divorce by simple registration at a ZAGS* office of civil registry; in effect under 1926 legislation, and put enormous constraints on divorce by stipulating that persons seeking divorce go through a long, complicated and costly procedure in two courts in order to get the permission required to register a divorce at ZAGS, upon payment of high fees. The second controversial provision of the 1944 edict stipulated that henceforth only registered marriage created the rights and duties of parents and spouses, and that neither rights nor obligations of extra-marital paternity would be recognized; whether through voluntary or involuntary establishment of paternity. Both these provisions of 1944 had as their main purpose the protection and "strengthening" of the family based on registered marriage, on the stabilization of families by

\footnotetext{
*ZAGS is formed fram the first letters of the Russian words for "registration of acts of civil status."
} 
legally protecting them from divorce and the shocks of a husband's outside liaisons; at a time when there were three wamen of marriage age for every two men. Pro-reform opponents of the 1944 edict came out against its "unLeninist" infringement of the principles of freedam of marriage and divorce, and equality of extra-marital children with children born in wedlock. 10

Eventually the Brezhnev govermment pried loose a chunk of the stalemated reform in a 1965 edict on divorce; effective January 1, 1966. The reform did not end court divorce, but made it easier by moving the second and final hearing from a higher court into the lower; or People's Court which had conducted the first; or reconciliation hearing, and by eliminating the formerly required expensive and delaying notice of divorce suit in the local press. There remain from the 1944 procedures the two hearings (reconciliation and final); the no-fault grounds of irreversible family breakup, and the registration fee ranging from 50-200 rubles. 11

The divorce law reform effective January 1, 1966 so eased the legal path that divorce rates shot up by 75 percent in 1966 over the 1965 levels, and never again went significantly below the 1966 level of 2.8 per thousand inhabitants. 12

This simplified court track to divorce remains in effect as incorporated into the family reform of 1968. In April of that year; there appeared in print for public discussion the draft of the Fundamentals of Legislation of the USSR and Union Republics on Marriage and the Family.13 It added a new constraint, serving in effect to protect wives; that a husband needs his wife's permission to divorce her if she is pregnant or within a year of the birth of her child, regardless of whether the child is his. ${ }^{14}$

Between publication and final passage by the Supreme Soviet on June 27, 1968 (effective October 1, 1968), after extensive public, professional, and 
governmental discussions; ${ }^{15}$ advocates of further reform achieved the inclusion of a second; non-court track of ZAGS divorce without prior court decrees in cases of mutual consent; and where there are no minor children of the marriage. As compared with the clear track to ZAGS divorce under legislation of $1926-1944,16$ the present non-court track is strewn with obstacles. Aside from the provisos about mutual consent and no minor children, there is a registration fee of 50 rubles (the court-decreed minimum on the other track) and a three month wait between application and registration. 17 Again we turn to statistics as a gauge of the impact of the law. This time, that is in 1969, unlike in 1966 after the court divorce simplications, rates did not go up. In fact they fell slightly from 2.7 divorces per thousand inhabitants in 1968 to 2.6 in 1969 and on through 1972.18

A typical, cautious Brezhnevian compramise, the present two-track divorce route to final registration at ZAGS joins a more difficult version of the 1926 no-court track with an easier version of the 1944 court track.19 This is not a complete return to "freedom of divorce." Rather, as a Soviet text puts it, the reform establishes "freedam of divorce under state control" so as to prevent "abuses of the right to divorce...contrary to the interests of socialist society and its effort to strengthen the family and improve the upbringing of children in it."20

Such limitations of freedam of divorce through "state control" are severe only compared with the Bolshevik legislation, but not by world standards. Judging by the latter; Soviet divorce law with its no-fault grounds, relative low costs and speed; remain among the most permissive in the world.

The edict of July 8, 1944 had allowed absolutely no recognition of a legal relationship between a father and his extramarital child. Only registered marriage created the rights and obligations of parents and 
spouses. The "Fundamentals" have partially eliminated this illegitimacy. Reformers got all they asked for in the matter of birth certificate and voluntary acknowledgement of paternity, but grounds for paternity suits were narrower than were those before 1944 .

Since the "Fundamentals" effective date, October 1, 1968, the rights and obligations of children born on or after that date no longer stem automatically from "registered marriage" alone, but from the broader base of "descent of the children as certified according to procedures established by law."21 The presumption remains that a registered husband is the father of his wife's child; unless he successfully contests this in court. ZAGS, the civil registry agency; will enter a woman's husband as father upon her statement alone; backed up by the marriage entry in her passport and other requisite documents testifying to the child's birth. 22

As for an unmarried father, he may now establish how own legal paternity, thus assuming all the legal rights and obligations of a father in wedlock, by jointly registering as parent with the child's mother, or by submitting a statement signed by himself alone if the child's mother is dead or missing. 23

When there is no legally established father, the mother and child no longer confront the notorious "blank space" under "father's name" as in the old form of certificate - a token of illegitimacy and a source of social stigma. In such cases, the unwed mother puts her own name as surname of the father, and any first name and patronymic (middle name) that she pleases. The child thus has a birth certificate looking like everyone elses, though no man is made legally responsible thereby. 24

To make a putative father legally responsible, a woman must sue in court to establish his paternity. But despite efforts of same reformers down to passage of the "Fundamentals," it did not restore the biological basis of 
paternity; a broad basis established by the 1926 legislation. Under present law laid down in the "Fundamentals" and carried into the family codes of the union republics; the courts will recognize a paternity suit only on the basis of three possible grounds established on the basis of evidence presented to the court: first; that the mother and the defendant lived together (not necessarily in one legal residence) and kept a common household (e.g., ate together; shared expenses); or secondly; that they jointly raised or supported the child; or thirdly (in a condition added between publication of the draft and final passage); that proof is provided which reliably establishes that the defendant has acknowledged his paternity in the past. 25 Examples of such reliable proof include a man's letter acknowledging a child as his own, or a photo signed "to my darling daughter Masha" and the like. 26

Where the man has not committed himself, where the child is born out of a casual union, a one night stand or even a longer relationship but one not providing any of the grounds just stated, the woman has no claim for support and the child no legal ties with its father, unless he voluntarily acknowledges paternity. This; say the supporters of broader grounds, is a violation of women's rights and equality, putting the burden of consequences on her alone. Criticizing the draft of the "Fundamentals" in vain during its discussion, three distinguished legal experts in the Research Institute of Soviet Legislation (a drafting think tank under the USSR Ministry of Justice) argued:

The draft clearly relieves married men in advance from responsibility to to children born outside their marriages, because as a rule they do not live with and maintain a common household with the mother of the child... The unequal status of the unwed mother contradicts the goals of Soviet family law. It not only resurrects harmful survivals of the past in attitudes toward women but also engenders in many young men a feeling that they are not responsible for their acts. 27 
Pulling out all the stops in their last ditch effort; these partisans of a return to paternity on the broad, biological basis argued that "the socialist countries which in many points have adopted the experience of the Soviet Union; have not followed it on the question of establishing paternity." They place no restrictions upon the grounds on which a suit to establish paternity may be filed. Hence, they asserted, women in the socialist countries are not unequally penalized for casual liaisons. "Children born out of wedlock must in all respects enjoy the same rights as children whose parents are married." 28

Reporting on the draft "Fundamentals" on the occasion of their passage by the USSR Supreme Soviet; party Central Comnittee Secretary; M. S. Solanentsev, who had chaired the drafting commission working on the final version of the law between April and July 1968, claimed that a majority of those expressing an opinion opposed absolute equality of rights if this meant unrestricted paternity suits. For the supporters of the law in its present form the law goes far enough as it is "to eliminate the elements of material and moral inequality of mothers and their children born out of wedlock..." To go any farther by lifting all restraints on paternity suits, Solomentsev reasoned, would make possible abuse of the law by wamen and "violation of the rights of the defendant named by the mother when he is not in fact the child's father." When mothers could press suits simply on grounds of biological paternity, the argument goes, this had "often led to serious mistakes in the past."29 In effect; then; images of possible abuses under a return to the paternity rules of the law between 1926 and 1944 and concern for the protection of men against unfounded charges of paternity; should the law return to its Bolshevik form, outweighed in the public rationale the 
promptings of ideology about women's equality which had prevailed in paternity law up to 1944.

The "good news" about the present law under the reform of 1968 is that it gives all children the same form of birth certificate, eliminating the notorious "procherk" or crossing out under "father" required for extra-marital children in the birth certificate forms used between 1944 and 1968. It is also "good news" for those fathers who could not legally establish their own extra-marital paternity between 1944 and 1968, but who wanted to and for various reasons were not able or willing to resort to the evasive ruse of adopting their own natural children. 30 It is "good news" to this day for extra-marital fathers wishing to acknowledge their paternity and assume the rights and obligations of fathers under the law.

Most of the bad news comes for mothers. Data on how the law worked out for them are scanty. We do have figures for Saratov Province, a region of 2.45 million inhabitants in 1970. Illegitimate, that is, extra-marital, births registered there in 1969 numbered 3,380. Only 175 paternity suits were brought in court, and in only 131 of them, or 3.89 percent of total births, did the court satisfy the suit and cause putative fathers to be registered and therefore to assume support obligations. Paternity was freely acknowledged in 50 percent of the births $(1,690)$, leaving mothers without paternal support in 46.11 percent of the cases $(1,559)$ - cases where no father had came forward. 31 These mothers had to rely on modest state allowances and other state assistance to unwed mothers, or hand their children over to the state to raise in orphanages. Of the three grounds for bringing suit, only one, cohabiting and maintaining a common household (though not necessarily common legal residence) proved effective. Contribution to support and upbringing is cited in a negligible number of rulings, past acknowledgment in a small 
minority of cases - about 11 percent in Saratov -- whereas the first ground; cohabitation and common household, appeared as grounds in 89 percent of the Saratov Province court decisions. 32

Two factors not apparent fram the face of the "Fundamentals" and the republic family codes based on it further limit the protection of unwed mothers. The law is not retroactive beyond the effective date of October 1 , 1968, except in cases of proven past acknowledgment. 33 Also, the recognized grounds for bringing suit--cohabitation and common household, joint support or upbringing, and proven past acknowledgment of paternity--will not stand up if the defendant is able to prove that he could not possibly be the father of the child. 34

Paternity law, like divorce law, is a compromise among conflicting claims on the law. The law's purpose, according to the government, is "to pramote the real equality of women and improve the standing of mothers..., to increase the responsibility of a citizen to the family and to society."35 The essence of the law itself is to strike a compromise between the rights and "standing" of mothers on the one hand, and the interests of men and "society" on the other. It is in the interests of men to be protected from paternity suits, and this they are substantially. It is in the "interests of society" to have stable families. Given the fact that about 10 percent of births annually, or 400,000 babies, are out of wedlock, 36 restricting paternity suits serves to protect, at least to some extent, families of men based on registered marriage fram the shock of suits by other women. This law is a compromise between the legislation and principles of Bolshevik days and the demographic and political imperatives of today. The law compromises between men's and women's rights. In this compromise, it is the men who get the better of the bargain. 
One should not stop here if one is to give a sense of the overall compromise and balance in family law as reformed in 1968. The law expresses other ways in which the government tries "to increase the responsibility of a citizen to the family and to society." A more serious approach to marriage is sought through the new rules of the refom lengthening the waiting period between application and marriage, provisions for invalidating "fictitious marriages" of convenience, and the requirement that ZAGS accompany marriage registration with a ceremony for those wishing it. 37

The past obligation to support a disabled and needy spouse is now extended to an obligation also of a husband to support a wife who is pregnant or has a child under one year old by the marriage. The obligation to support continues after divorce, if the pregancy began before divorce, until after the birth of the child. Courts have the discretion also to award alimony to a divorced spouse who is needy and disabled, without stated time limit (under old law the limit was one year), if the spouse's disability began before divorce or within a year after divorce. After a long marriage, the court has the discretion to award alimony to a divorced spouse if the spouse reaches retirement age within five years after the divorce, 38 retirement age for the courts meaning 55 for women and 60 for men in all cases. 39 Present law also bends existing community property rules of equal division in effect since 1926 to favor an especially needy spouse (for example, a spouse who is disabled or raising minor children) or to penalize unworthy conduct of a spouse by awarding him or her a less than equal share of community property for drinking away or otherwise squandering money, doing no socially useful work, "and in other appropriate cases." 40

As regards parents, the law moves, again in the direction of enforcing greater responsibility toward the family by adding to grounds for deprivation 
of parental right such as cruelty and neglect; the additional grounds of "exerting a harmful influence on their children through their immoral, antisocial behavior, and also if the parents are chronic alcoholics or drug addicts." 41 The law has been directed against parents who are members of dissident religious sects or who violate laws against organized religious instruction of children. 42

In its present $\mathrm{mix}$ of freedoms and obligations, rights and responsibilities, Soviet family law has been tailored to fit the values and behavior of Soviet people more closely than did the law under the Bolsheviks, who sought to impose new socialist values and attitudes, or the law under Stalin, who sought to impose discipline and governmental interests that accorded with his perception of societal needs of peasant households during collectivization by administrative and legal measures lying outside family law, and during the consolidation of socialism, through the family legislation of 1936 and 1944. Given the non-revolutionary tenor of the times within the USSR, this adjustment is not surprising.

Breakdown:

Nor is the breakdown, of many families in recent years surprising, at least to outsiders. For the Soviet Union traversed all the unsettling stages of development such as rapid urbanization associated in the West with rising rates of divorce and falling birthrates, an extraordinary rate of female employment and growing independence, a particularly rapid erosion of the economic and moral basis of family solidarity, coupled with the particular strains and tension in the family associated with women's high employment outside the home and double burden at work and at hame, virtually a "second shift," or some two to 2.5 times more housekeeping work than is performed by men in the USSR. 43 
Families in advanced industrialized countries have tended, with few exeptions, to become smaller, more fragile and less fertile replenishers of society, as a perusal of the United Nations Demographic Yearbook will show. The family in much of the USSR outside areas of Moslem tradition is not one of the exceptions. The average family size has been going down, as Table 1 shows, though the number of families continues to grow, to an estimated 70 million by 1983. Over four fifths of all families have four members or fewer. The biggest Arop in size since the 1930s has been in rural families, traditionally the main source of population replenishment, reflecting declining fertility, rapid out-migration, and an aging of the population as a consequence. Only in areas with high proportions of people of Moslem background (often still professing Moslem beliefs and identifying with a Moslem tradition) has the family been growing. In Tadzhikistan, for example, the average family size is 5.7 persons and still increasing, as compared with an average of barely over three persons in the Baltic areas and the national average of 3.5 persons. 45

Table 1. Average Family Size, USSR, Urban and Rural Families.

\begin{tabular}{lllll}
\hline Year & $\begin{array}{l}\text { No. } \\
\text { (Mlns.) }\end{array}$ & \multicolumn{2}{c}{ Number of Members } & Rural \\
\hline & & & Urban & \\
1939 & 42 & 4.1 & 3.6 & 4.3 \\
1959 & 50.3 & 3.7 & 3.5 & 3.9 \\
1970 & 58.7 & 3.7 & 3.5 & 4.0 \\
1979 & 66.3 & 3.5 & 3.3 & 3.8
\end{tabular}

Sources: 1939: A.G. Kharchev, Brak i sem'ia v SSSR (Moscow, 1964), 215; Ts.S.U. Itogi vsesoiuznoi perepisi naseleniia 1959 goda. SSSR, Svodnyi Tom (Moscow, 1962), 13, 244; Ts.S.U. Itogi vsesoiuznoi perepisi naseleniia 1970 goda. VII (Moscow, 1974), 4; Narodnoe khoziaistvo SSSR v 1979 godu (Moscow), 1980), 35. 
Average family size has been dropping among the populace of European descent owing to changes in life style and health. The numbers of family members living under one roof have been depleted by the breakup of extended, multi-generational families as the generations of parents and grandparents take up separate dwellings, and by rising rates of adult mortality 46 as well as of infant mortality. 47 Adverse trends in divorce and birth rates also have left their mark on family size.

Divorce rates quadrupled between 1950 and 1965, from 0.4 to 1.6 divorces per thousand inhabitants, owing both to liberalization of court practice after Stalin and to advancing urbanization. 48 They rose again from 2.8 in 1966, the year divorce law reforms went into effect, to 3.6 in 1979 and 3.5 in $1980^{49}$ a rate second only to that in the United States, a more urbanized country, and a rate which Soviet opinon finds "very high" and troubling. 50 According to a Soviet estimate, one of every two marriages in the USSR is seriously wracked by conflict and tension and hence unable to perform adequately its social roles of emotional support and child rearing. 51 According to Soviet analysts, this "further deterioration of marital relations in recent years" signalled in the divorce statistics contributes to the population problem confronting Soviet policy makers going into the 1980 s. 52

Behind the breakdown lies the story of one of the world's great internal population movements this century, from villages to urban areas. The ratio of urban to rural inhabitants has doubled in the twenty years between 1959 and 1979. Two thirds of the approximately 70 million Soviet families today live in urban areas; that is, in areas with lower family fertility than exists in the rural hinterlands of the country. As a result of the decline in family fertility, aging, and higher mortality rate of the population, the natural increase (births minus deaths) per thousand inhabitants has dropped from 17.4 
in 1959 to less than half that today--8.1 in 1979 and 8.0 in 1980. This rate is higher than that which prevails in the U.S., Japan, and the rest of Europe, but it is still not high enough to prevent a precipitous drop in the growth of the Soviet labor force, as a smaller contingent of young workers replaces a much larger older contingent moving into retirement, a potential blow to the labor-intensive and full-employment economy of the USSR. 53

High birthrates among the Moslem population of Azerbaidzhan, Kazakhstan and the Central Asian republics of Uzbekistan, Turkmenistan, Tadzhikstan and Kirgizhia do little to soften the blow. Against the econamic and political interests of society and the state, Moslems in the countryside remain attached to their native villages and their large, close families, 54 and unavailable to labor-short urban areas. Small, infertile, unstable, and mobile European families tend to live in these labor-short areas. Large, fertile, stable, and immobile Moslem families tend to live in labor-surplus areas, yet provide the main pool for workplace replenishment in the 1980s and beyond. As a Soviet economist sums up the demographic situation:

The population of the Central Asian republics, Kazakhstan and the Caucasus increased by 61 percent in the period 1961-1980, but it rose only 16 percent in the Russian Federation, Ukraine, Belorussia, and the Baltic republics. The highest increase in the able-bodied population today is in the republics of Central Asia, Kazakhstan, Azerbaidzhan, and Amenia. Over the next ten years ${ }_{55}$ these regions will account for practically all manpower reinforcements. 55

Possible economic and political complications arising fram this maldistriubtion of population growth may be exacerbated by the growing regional separation of persons of European and non-European descent. This trend is usually passed over in depictions of the population maldistribution. But it should be kept in mind during any discussion of the declining share of Russians and increasing share of Moslems in the Soviet population. For this regional polarization tends to accentuate any political 
and econamic effects of the maldistribution of population growth. The census figures on the nationality composition of the union republics of 1959, 1970, and 1979 show an increase in the proportion and absolute numbers of Russians in every European republic (Baltic, Slavic or Moldavian). They show a decrease since 1959 and 1970 in the proportion of Russians in every nonEuropean republic (Georgia, Armenia and Azerbaidzhan; Kazakhstan; the four Central Asian republics), plus an absolute decrease of Russians in Uzbekistan, Azerbaidzhan and Georgia. This polarization of settlement, along with an ongoing Moslem national self-assertion in Soviet econamic and cultural affairs, poses economic and political problems for the soviet regime. 56

The "acute population problems" of the Soviet Union are attributed by Dr. D. I. Valentei, head of the Population Studies Center of Moscow University, to the sort of breakdowns in the family I earlier described:

In the first place, a drop in the birthrate; unfavorable trends in mortality, especially in children and or persons of working age; in the large gaps between the life expectancies of men and women. The number of divorces and incomplete families continues to cause great anxiety. ${ }^{7}$

The picture that Americans draw of families in the United States is much the same:

Divorce rates are climbing; marriage is being postponed, if not rejected; fertility rates are falling, increasing numbers of children are being raised by their mothers, either because of divorce or because their parents were never married.

What disturbed the Americans writing this, however, was not falling population growth but the breakdown of social values and stability. 58 The United States government funds extensive family-support programs, but without any coherent national family policy; in fact without any coherent national family policy at all.59 Concern in the USSR over family breakdowns extends to their demographic effects also, as in East Europe, France and West Germany. Unlike the U.S., all these countries possess coherent demographic policies. 
The head of the first department of family affairs in a local soviet (government council), that of Moscow, commented that "the family is living through a difficult period."60 How has the Soviet government responded? Ideology and Change:

The regime's first step was to turn for advice to the specialists in the reborn fields of demography and sociology. To speed the recovery of their research after years of its repression under Stalin, the specialists have referred frequently to "bourgeois" research in the West for guidance as to methodology and family trends and causes of family breakdowns in other advanced industrial societies. They make much more use of Western sources in the study of Soviet families than Westerners make use of Soviet findings in the study of families in their own, Western countries. 61 This is partly because of the need to catch up in family-oriented research and for urgent reasons of state - namely, the declining growth in the available labor force. Partly it reflects a basic and, to the foreigner, perhaps startling ambivalence toward Western research.

Empirically, Western research is considered a model and source of valuable insights and apprọaches. Ideologically, Western research is to be refuted, when it begins to talk about the "convergence" of Soviet and Western families because they are breaking down in so many similar ways. It appears obligatory for soviet researchers to reassert the superiority of soviet socialism over Western capitalism and, therefore, the brighter prospects for the Soviet family. Generalizations linking family breakdown to any inherent aspects of socialism rather than transitional problems of urbanization and growth generally are avoided in published texts and articles. 62 Part of the "social command" to Soviet scholars is not only to recommend measures of family policy on the basis of their empirical research, but also to expose 
"bourgeois scholars' distortions of Soviet reality," bourgeois "cover ups" and "apologetics" for the "degeneration" of Western families and society. 63

Soviet specialists must at once base their research into family change on "historical materialism" (by relating the changes to particular economic systems -- capitalism, socialism, etc.) and conduct empirical and methodologically sophisticated research into specifics of the Soviet family's performance so as to be reliable policy consultants. 64 Their dual role of political legitimizers and social therapists makes family researchers into advocates of the constitutionally proclaimed superiority of "mature socialism" under the leadership of the Communist Party, depicting a Soviet socialism which "creates all the necessary conditions" for the regime's pramotion and achievement of a "newer, higher type of family,"65 while warning of the "substantial complications" for the family inherent in the developmental processes of socialism and the protracted and strenuous efforts required to overcome them. 66

After a bow to the obligatory formulations about "survivals of the past" and "non-antagonistic contradictions", Soviet texts enter the everyday world of family tensions associated with woman's double burden at work and home yet her greater independence and demands on marriage these days; the "moral vacuum" in family values and sexual relations in the urban environment; the material difficulties still inherent in starting a family; the "ineffectiveness" of the family as a reproductive unit for bearing children and educating them because of its instability and the cross pressures upon parents.

I do not mean to dismiss ideology as a hindrance to elite cammunication about the family. The ideological defensiveness aiout all soviet social problems inhibits organized East-West exchange and joint East-West research on 
family breakdowns and other such social problems. Straight talk about sexuli adjustment and pre-marltal sex i.s r.ace.68 Wife and child abuse are virtually taboo subjects. Also, the history of the family under soviet rule leaves enormous gaps covering perlods of devastation wrought by Stalın's collectivization and purges. 69

Sovlet family policy has reflected the regime's responses to fumlings of demographers as well as of tamily sociologists. Demographers encountered their own particular version of Lleiological and bureaucratic obstacles as they rescued their field fram Stallnist oblivion during the early 196ns. An optimustic "soclalist law of population," predicting intensive and optumal population growth under soclalism limited the value of the findings in even such a grourkt-ibreaking work as Borls iJrlanis's Fertillty and Llfe Fixpactancy in the US.SR puliolished in 1963.70 Yet already two years earlier, a British analyst had correctly forecist a declining population growth in the USSR, using cenius daca avallable also to Soviet researchers. ${ }^{71}$ Meanwhile Soviet demographers were quotıng Khrushchev's arilently pronatalıst teachıng that "our country will be stronger the more people we have," 7 ? and an inaccurately optunistic forecast came out of the Central Statistical Artnunlstration $(\operatorname{CSA}) .73$

Then two events helped unshackle : luxuxyraphy: Khrushchev fell from power Ln Detober 1964; and in the later 1.950s, burthrates and polnilition growth in the USSR and Eastern Furope were Aropping to the level.s DE ATY countries. ${ }^{74}$ Beginning th this time, some demogripilurs openly attacked the Demographlc Department sf the SAA and lts head, P. Pod"iachikh, something inconcelvili)l.e without support within the party leadership. These demographers dismisistal several heretofore ideologlutl. "inus"s" including the "soclalist law of populacion." They openly rejected che CSA's population pritiliction and forced 
its re-calculation. They discredited the CSA stand that demographers should Inerely record vital stat.lsti.ss, but not attempt to analyze them or offer advice on policy.

With the support of the party and administrative agenezes, demography emerged as a separate field of research and analysıs, drawing on ivestern work to derive models ank inethods applicable to the USSR. ${ }^{75}$ Had the party leadership not seen a vital interest affected potentially by slowdowns in the famlly, demographers would probably nave cemalned glorified recording clerks.

A remaining, lieologlcally-based obstacle to demographic research his been the growing re-unposition of secrecy over more and more statistics about census results, fercility, mortality, and their breakdowns by age, sex and region. Statistics on national abortion rates simply are not published. 75 nermographic Issues:

Whecher published or unpublished, statistics on declining population growth and diminıshing new labor reserves stimulated a lebate over demographic [xllcy. The central issile has been, what, if anytining, should be done to arrest and reverse the breakdown in tine Eamlly's procreative function, and to stimulate burthrities beyond the fading remnants of a once more actlve pronatalist policy. 77 What could and should be done to relieve wamen's itoulule burden of homemaking and outside work? kcoording to soviet experts, no breakthroughs in women's 'zonditions of work and rest, or in everday services io ligirren their housework, occurred during the Tenth Flve-Year plan (19761980). Work continidel is retilect a severe conflict with maternal

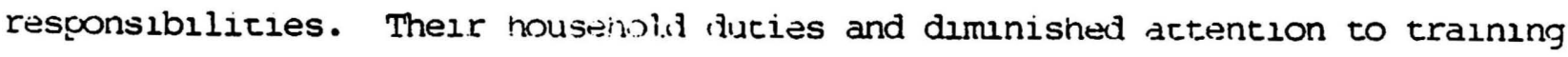
and caczer affer marriage, especially after chlldbirth, caused women co lag ever farther 'whind the men wich whom they stitited : In even terms. 
The proportion of women working night shifts is still large; also that of women doing manual, low-skilled work. The employment of women in unskilled labor is a reason why women's average wage is two thirds that of men although the total load at home and at work is 15-20 percent higher than that of men. 78

As if the obvious difficulties of diverting scarce resources fram economic and military uses to birth stimulation were not enough, the regime received very divided counsel from the demographers. This division reflected knotty dilemas of policy set deep in ambivalences about the proper roles of women as mothers and workers, the short term gains of keeping them working versus the long term gains and costs of paying them more to interrupt their careers so as to bear children, about how to respond to birthrate differences between families in Moslem and European areas. Strong opposition to an activist demographic policy, moreover, centered in the CSA, the informational heart of the administrative bureaucracy. As of the late 1970s, prospects for a new pronatalist policy seemed dim to many outside observers. 79

Consensus existed among the experts only on two points. First, any consideration of demographic policy, pro or con, centers on the family, the biological source, "one of the important levers of demographic policy, which is, in essence, family policy." 80 Second, there should be no return to compulsion, such as a ban on non-therapeutic abortions -- the practice in the USSR from 1936 to 1955, which also prevails today in Romania and, partially, in Czechoslovakia, Hungary and Bulgaria. 81

Beyond this consensus, the demographers gave the regime conflicting advice. One opinion grouping among them opposed pronatalist policies as not cost effective, and detrimental to the equality of women. A second group tried to meet these objections by proposing pronatalist policies that would upgrade the quality of life for working mothers rather than make payments to them as inducements to stay home and raise children. A third group advocated 
an activist pronatalist policy centered on substantial family allowances for the first to third child, and on lengthening the paid maternity leave to a year. They divided over the issue of whether to discriminate against fertile national minorities in the less industrialized areas like Central Asia. 82 In the end, a campramise was affected in this politically sensitive area.

Opponents of pronatalist policies mustered around A. G. Volkov, head of the Demographic Department of the CSA's Research Institute. Volkov and his colleague, A. G. Vishnevskii, opposed new birth stimulation measures as too costly in terms both of women's full development in work and social life, and of the quality of child rearing. It was superior, they maintained, in a small family due to the amount of attention that a child requires and the limited time modern parents have to devote to raising children. They also cited the immediate economic costs should more women withdraw fram the labor force to bear children, and the high costs of the additional day care facilities and medical care needed as a result of a birthrate increase, costs which would divert funds from other social needs. Volkov and Vishnevskii prefer quality of population over quantity. of population in demographic policy. For Volkov, "Soviet society will attairi its broad social goals not so much by increasing the quantity of population as by improving its social quality," that is, its attitudes, skills, health, "harmonious development of character," all of which requires additional budgetary outlays on the part of the government. 83

As for the interests of family and society, Vishnevskii claims that they are best reconciled by the current "demographic revolution," a favorite expression of Vishnevskii's. By this he means the shift in the USSR (as in other industrializing countries) fram high fertility and high mortality to low fertility and low mortality. What is good for the small family is good, Vishnevskii argues, for Soviet socialist society. He maintains that the 
quality of life in such a family is better for both women and children than it is in large families, under modern conditions of urban life and full employment prevailing in the socialist society of the USSR. Both Volkov and Vishnevskii dismissed, as groundless 84 or "overdramatizing", 85 the warnings of pronatalists that falling population growth could lead to eventual depopulation and calamitous drops in available labor force in the 1980s.

Two other arguments advanced by them probably lost ground for their position. Anticipated labor shortages, they argued, can be overcome by influencing migration and by increasing the productivity of labor, the efficiency of production and the distribution and utilization of labor resources. 86 One problem with this argument is the present difficulties the regime is having with increasing labor productivity. 87 The contribution of labor productivity to industrial growth has lagged far behind plan, as has growth. This has put a greater onus than planned on labor recruitment to maintain economic growth. Labor productivity has risen after Brezhnev, though how permanent this increase will be is not clear. 88

The pronatalists, V. I. Perevedentsev and the late B. Ts. Urlanis, have said that the international prestige and power of the Soviet Union rest on population growth and that these are threatened by the declining share of Soviet population in the world total. Volkov argued that Soviet power and prestige rest not on the quantity of the population but on the quality of its contribution to economic and technological progress. This progress and the Soviet system itself are the true measure of soviet greatness. 89 One wonders whether Perevedentsev and Urlanis might not have been more convincing than was Volkov to anyone considering their arguments in the sentimentally pronatalist leadership of an often beleagured land power whose spaces and human resources saved it in the past. 90 
over the years; in fact; the soviet leadership had shown a growing pronatalist predisposition. Brezhnev called in 1971 for a "forecast of the growth of the nation's population."91 Five years later, he warned researchers "not to lose sight of population problems which have become acute lately." Revealing his pronatalist assumptions, Brezhnev ordered the drafting of an "effective demographic policy."92 Almost every writer, it seems, quoted those remarks. It is by no means clear whether Brezhnev was telling the demographers what he wanted to hear, or whether the demographers had been telling Brezhnev what they wanted him to hear. 93 There is probably some truth in both sides of this question. Brezhnev left no doubt of his pronatalist inclinations in October 1976, telling the Central Camittee of the party that "population problems have become more urgent recently and require an effective demographic policy."94

Another disadvantage for the opponents of more birth stimulation, like Volkov and Vishnevskii, has been that their Demographic Department of the CSA's Institute is not as central to the leadership and coordination of research as are other institutions, all more or less pronatalist in stance. Dr. D. I. Valentei, a moderate pronatalist, heads the generally pronatalist Center for Population Studies of the Economics Faculty of Moscow University. The Center is a large teaching and research organization set up in April 1968 by merging the Population Problems Laboratory and the Population Department. It has has among its sponsors USSR Gosplan, the State Council of the Council of Ministers for Science and Technology, and the Presidium of the USSR Academy of Sciences. According to Valentei, the Center "fulfills the role of the leading organization for working out the socio-economic bases of population growth and the methods of managing and regulating it."95 Pronatalists like Valentei and Urlanis as well as opponents of pronatalism like Volkov have been 
consultants for the Scientific Council of the USSR Academy of Sciences on the Social and Econamic Problems of Population to help it draft plans for demographic research.96 T. V. Riabushkin, a leading figure in the restoration of Soviet demography and director of the Institute of Sociological Research of the USSR Acaderny of Sciences, has specifically refuted the non-active stance of Volkov and Vishnevskii in family and demographic policy. Like Riabushkin, the journal Sociological Research takes a pronatalist stance; as he does, the journal strikes a balance between promoting quality through measures to maximize supportive services to women and reducing the conflict between work and motherhood, to combat mortality, improve upbringing, etc. 97

A third position in the demographic debates was taken by experts who, though pronatalist, still shared the concern of the antinatalists, Volkov and Vishnevskii, for quality, and their belief that family attitudes on the ideal number of children are beyond the reach of economic incentives like family allowances and grants. But their way to avoid putting women back in the nursery while raising family fertility to levels of people's ideals, as recorded in CSA surveys by L. E. Darskii, V. A. Belova and others, 98 is virtually to eliminate family educative functions and greatly reduce its economic functions by communalizing upbringing and housekeeping services. For these qualitatively oriented pronatalists, improved day care and family services are preferable to increased allowances for both ideological reasons of women's equality and practical reasons of the large contribution women make to the labor force. 99 Soviet researchers have discovered, as in the West, that birthrates and family size do not go up but go down with increased urbanization, higher incomes and educational levels and rates of women's employment. 100 The pronatalist opponents of financial birth stimuli argue fram this that non-economic motivations determine women's reproductive 
choices; such as how much having children interferes with their career and other interests.

Pronatalists on the other side of the quantity-quality balance are well aware of the need for a broad-based demographic policy. Yet they are anything but confident in state nurseries because of serious problems of infection rates and low standards of staffing in some of them. ${ }^{101}$ They discern a need to increase population growth rates, and prefer to put at the center of their proposals partially paid leaves of up to at least a year from childbirth and economic measures to encourage families to have not one or two but two or three children. They do not ignore problems of quality, but they stress quantitative problems. Without added economic inducements like the leave and generous lump sum and monthly allowances for mothers of two and three children, preferential access of young families to housing, etc., pronatalists like Urlanis and Prevedentsev say, women will not be induced to have the 2.12.2 children each on the average, the minimum for simple reproduction of the population, to prevent eventual population decline. 102

More efficient use of labor will not by itself solve the labor shortage, in the pronatalist view. 103 E. L. Manevich, a leading labor econamist, agrees. Manevich is head of the Sector of Labor Problems of the Institute of Econamics in the USSR Acaderry of Sciences. What disturbs him is the prospect that the growth in working age population will drop in the 1980 s to only 3.8 percent as compared with 18 percent in the 1970s.

Regional Differentials?:

Once the Soviet regime decided to opt for a new demographic policy of birth stimulation, it faced the tangle of thorny issues posed by the much higher fertility rates among families of non-European nationality, especially families in nationalities of Moslem origin, like Uzbeks, Kazakhs, Kirghiz, 
Tadzhiks; Turkmens; and Azerbaidzhans. Quite possibly, the political questions associated with Moslem self-definition and assertiveness and the growing Moslem share of the population lurked in the back of many people's mind during the demographic debates. 105 But the demographic and economic issues of where and how to differentiate in any birth incentives program posed problem enough. Should such a program differentiate regionally? If so, should it operate in favor of the low-fertility regions of mainly European settlement? Should benefits to Moslem areas like Central Asia actually be reduced? To what extent should the regime count on being able to use the surplus population within the boundaries of its republics? If it decides against forcing or promoting out-migration fram those republics, will it have to divert water from the mighty Siberian rivers, the Irtysh and the ob, to irrigate the land to feed the Central Asian population as part of the region's accelerated development? 106

That all these questions exist, and persist, traces down ultimately to the behavior of the family in Moslem areas - prolific, extended, stable, homebound and rarely inter-marrying. 107 As the rural family of Central Russia and the Urals falls apart, $25-30$ percent of the rural populace there migrates away from the village. Members of indigenous families in Caucasus villages at least move to cities within their republics. But only five percent of the indigenous population in the Central Asian countryside migrates to cities in the same republic, let alone to other labor-short republics. 108

A major article in Pravda has pointed to the role of family differences in causing differences in population reproduction and growth:

Serious differences remain in this sphere, namely, the predaminance of one or another type of family relations-the multigenerational, traditional family or the so-called nuclear family (parents and children of the next generation). On this depends whether the population of a republic is aging or youthful, becomes a smaller or larger part of the economically active population. 
Each demographic situation produces its own social and cultural problems. The preservation of the traditional, multigenerational family as a rule does not facilitate the development of new forms of everyday life, nor the recruitment of women into active production work. It is often accompanied by insufficient migratory mobility of the population, with the carrying over of customs hampering young people's leaving their own regions where they were born. 109

Never mind the differences and the maldistribution of family fertility, say opponents of a differentiated demographic policy like the demographer Perevedentsev and the labor economist Manevich. We need all the people we can get. Without the Central Asian fertility, says Perevedentsev, the Soviet Union would already have dipped below the reproduction levels sustaining even zero populatin growth. Besides, says Manevich, discrimination against any nationality region would violate the Soviet principle of "a single nationality policy," of the equal treatment of all nationalities, "one of the principle attainments of Leninist nationality policy," and would go against the CPSU General Secretary. 110

Many pronatalists parted company with Perevedentsev and Manevich on the issue of differentiation. 111 Notable among them for their strong stand and prominence in the general debate have been Urlanis; G. I. Litvinova, a jurist in the Institute of State and Law; and A. Ia. Kvasha of the Center for Population Studies at Moscow University. Urlanis long favored greater birth incentives for regions of low fertility and smaller benefits in regions of high fertility with surplus and immobile populations. 112 Both Litvinova and Kvasha fault the large family in high fertility regions for hampering the emancipation and equality of women there and producing a poor "quality" labor force-undereducated and almost unassimilable into the urban labor force. ${ }^{113}$ Both of them want the Bulgarian scheme: lump sum grants plus monthly allowances to mothers beginning with the first child, peaking at the third, dropping back to a low level for the fourth and all subsequent children. As 
Table 2 shows, the family allowances decreed in 1944 and 1947 after the losses of World War II, and still in effect, begin only with the third living child (for lump sum birth payments) or fourth living child (for monthly allowances) and reached a peak with the ninth and eleventh child, respectively. The proposed new differentiation would have reversed this situation in favor of small families.

As Litvinova pointed out, the change would have ended a situation in which the bulk of birth incentives has gone to high-fertility areas. ${ }^{114}$ The geographic distribution in 1980 of awards of Mother Heroine medals and titles to women who have borne and raised ten children, outlined in Table 3, points this out graphically. Of 20,475 awards of Mother Heroine reported in the gazette of the USSR Supreme Soviet, 13,511 or 87 percent of them went to mothers in the four Central Asian republics, though they contain only ten percent of the Soviet population. Awards per 100,000 inhabitants ranged from 0.4 in Latvia to 66.3 in Tadzhikistan. Award rates in Tadzhikistan were nearly 50 times those in the RSFSR and nearly 100 times more than in the Ukraine!

Since at least 1976, the issue for the regime seems to have been not whether to launch a pronatalist program, but how to combine birth stimulation payments to mothers with investments to improve the quality of life of mothers and their families. Also, the issue has been--and still is, as we shall see-whether to give new benefits in equal measure all over the USSR, whether to keep old benefits favoring fertile non-European nationalities in the border republics to the south and southeast, or whether to discriminate against those border republics, as some in the Russian part of the country have so strongly and frankly urged. 


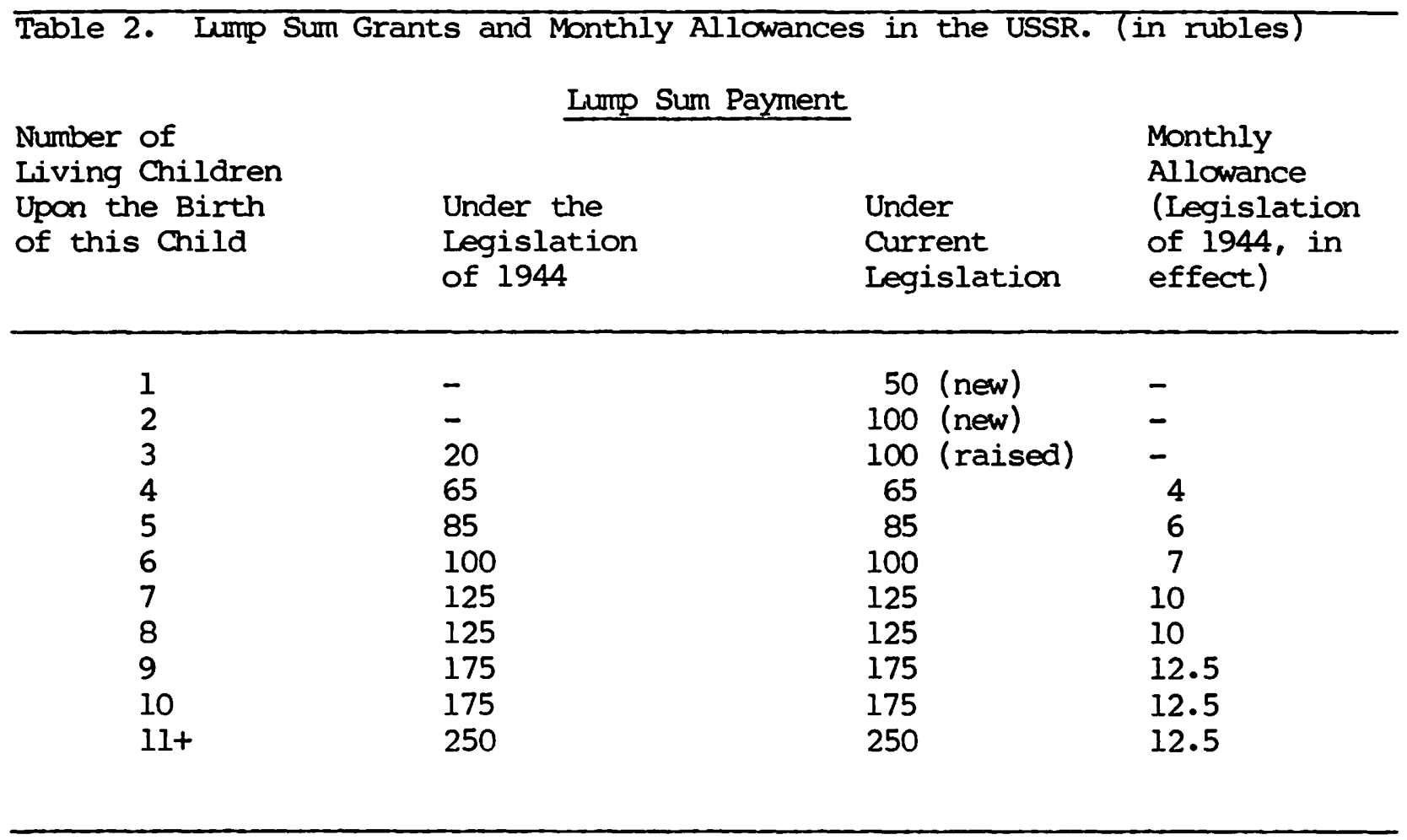

Sources: Okhrana detstvo v SSR (Moscow, 1979), 188; Pravda, March 31, 1981. 
Table 3: Awards of Mother Heroine in 1980, by Union Republic and per 100,000 of the Republic Population.

\begin{tabular}{lrrr}
\hline Republic & Awards & $\begin{array}{l}\text { Awards per } \\
100,000 \\
\text { Population }\end{array}$ & $\begin{array}{c}\text { Midyear } \\
\text { Population } \\
\text { (mln.) }\end{array}$ \\
& & & \\
\hline RSFSR & & 1.4 & 138.80 \\
Ukraine & 1982 & 0.7 & 50.05 \\
Belorussia & 351 & 0.5 & 0.64 \\
Uzbekistan & 48 & 49.3 & 15.97 \\
Kazakhstan & 7879 & 19.0 & 14.96 \\
Georgia & 2838 & 1.9 & 5.06 \\
Azerbaidzhan & 104 & 23.1 & 6.16 \\
Lrthuania & 1425 & 0.7 & 3.43 \\
Moldavia & 24 & 2.6 & 3.98 \\
Latvia & 104 & 0.4 & 2.53 \\
Kirghizia & 11 & 39.5 & 3.62 \\
Tadzhikistan & 1431 & 66.3 & 3.95 \\
Armenia & 2622 & 20.6 & 2.86 \\
Turkmenistan & 66 & 55.2 & 1.48 \\
Estonia & 1579 & 0.7 & 265.60 \\
USSR & 11 & 7.7 & \\
& 20475 & & \\
\hline
\end{tabular}

Sources: Vedomosti Verkhovnogo Soveta SSSR, camplete for 1980. Population estimated from Narodnoe khoziaistvo SSSR v 1980 godu (Moscow, 1981), 7 Awards rates estimated fram other two columns. 
Pronatalism for the Family:

A compromise policy of birth stimulation emerged finally in the Guidelines for the Eleventh Five-Year Plan at the 26th Party Congress (1981) and in subsequent decrees. 115 Reflecting the limited general consensus, the new program avoids a return to the compulsion of abortion bans as a means of increasing birthrates and centers on assistance to the family. Said Leonid Brezhnev:

As instructed by the 25th Party Congress, the Central Camittee has paid serious attention to formulating and implementing an effective demographic policy and to the recently more acute population problems. The main way to solve these problems is to increase concern for the family, newlyweds and, above all, wamen. (Applause.) For we all know that sometimes it is very difficult to combine the responsibilities of a mother with active participation in production and public life. 116

The Guidelines of the Congress for the Eleventh-Five Year Plan (19811985) cormitted the regime to a pronatalist package of quantitative investments (in family allowances) and qualitative improvements (in the family's environment of services, child care, and public health); "to help strengthen the family as the most important primary unit of society; to create optimal conditions for women to combine motherhood with an active career; to improve public support for children and the disabled; to implement a series of measures to increase people's life expectancy and ability to work, to strengthen their health."117

On the quantitative side, the often-suggested monthly allowances for first, second, and third children surprisingly did not materialize. There has been, however, an increase in the monthly allowance for unwed mothers, fram 5 rubles per child up to the age of 12 , to 20 rubles per child up to the age of 16, or up to 18 if the child is at school and without a stipend. This appears 
aimed at lowering abortion rates among unwed mothers and mitigating the difficulties of single parenthood, however slightly.

Since November 1, 1981, the pension age has gone down five years (to 50) for wamen raising five children to age 8 , or one invalid child. To qualify the women must have worked at least five years, three of them continuously. The tax on childless persons 118 is waived for couples for a year after registration of marriage. Working mothers receive three extra days paid vacation up to 28 calendar days. There are additional, but vague, benefits. They are to receive flexible vacation scheduling, subject to agreement of the management and production conditions permitting. Paid leave to care for a sick child is slated to rise from ten to fourteen days, and discounts on children's products are to expand.

The main new benefit payment is the modest monthly allowance of 35 or 50 rubles during an optional, partially paid extra maternity leave (after the existing 112-day fully paid leave) up to one year after childbirth (plus yet an extra six months of unpaid leave), for mothers who have worked at least one year or are studying while on leave from work. This benefit has been differentiated in size and time on a regional basis. The new 50 ruble allowance was first introduced on November 1, 1981 in the most depleted and underpopulated regions: the Far East, Siberia, northern Russia (Karelian and Kami Autonomous republics, Archangel and Murmansk Provinces, and the depleted old northwest Russian provinces of Vologda, Novgorod, and Pskov). The 35 ruble allowance was introduced to the rest of the Russian republic and to the Ukrainian, Belorussian, Moldavian, and the Baltic republics on November 1 , 1982, and in Kazakhstan, Central Asia and the Caucasus on November 1, 1983. 
The same; three-stage schedule applied to the new lump sum payments to small families: 50 rubles for the first child, 100 rubles for the second and third. Table 2 shows that lump payments drop to 65 rubles for the fourth child, then rise to 85 for the fifth and 100 for the sixth and subsequent children. So the differential is far less severe than that advocated by Litvinova, Kvasha, Urlanis and others and preserves, against their recommendations, the large-family allowances under the 1948 tariff - a cautious compramise at least in the family sphere of nationality policy. Moreover the measure leaves in effect a family income assistance decree of 1974 which favored large families. 119

True, housing assistance and other help for newlyweds is partly differentiated by region. Vaguely it is said that newlyweds up to the age 30 may receive at least a roam to themselves in Siberia, the Far East, northern Russia, and the non-Black Earth region. If they have a child during the first three years of marriage, then they get a one-roam apartment, or so it is intended. As of April 1, 1982, couples began to receive 1500 ruble, interest free loans to help them set up house and pay for parenting after the birth of their first child and if they are under 30 years old, have good references, and one of them has worked at the lending organization (firm, collective farm, institute, etc.) for at least two years. The loan is being introduced first in the top-priority regions listed earier for first receipt of leave monies, then in the second and third priority regions on April 1, 1983 and April 1, 1984. Repayment is due in eight years, but reduced 200 rubles for the second child, 300 rubles more for the third child. These loans, nearly a year's average salary and convertible into substantial birth incentives, are still modest compared with the East German program (where of course living 
standards generally are higher) and compared with the difficulties and costs of acquiring one's own housing. $12 n$

On the qualitative side, we find directives for enhanced support services, e.g., for the "widespread dissemination" of a part-tıme flexıble schedule for working mothers and "serious improvement" in varlous services so as to lighten the burden of housekeeping. Day care institutions are to keep expanding, prımarlly in .areas of high female employment, and diets supposerll.y to be improved in the nurseries and kindergartens. Nurses in the creches are to receive the same six-hour day and 36-hour week as do attendants in kindergartens in order to help upgrade their personnel. Health care in the USSR, it has already been mentioned, has been lagging and much criticized, as recently as at the 26 th Congress. It is as yet too early to tell the effects of a major decree of August 1982, "On Additional Measures to Improve Health Care for the population."121

The other problem in lowering mortality and illness, environmental pollution, evoked a long list of directives at the 26th Congress. But in the USSR, environmental protection laws are often ignored or resistetl. Environmental dangers appear to be mounting faster than resources are being made available to deal with them.12? Reducing environmental disease and death will. be many times more costly, mexical demographic opinion notes, than was the elimination of infectlous diseases like smallpox or typhus. 123

prior to this pronatalist, prokage of benefits and services, speclal assistance to newlyweds anil sintl families had occurred only in a few rentarive local efforts. 124 For some decades, also, the cegime has kept up a iro-family campaign at tine symbolic level of "new clvil ceremonies" solemnizing rites of passage? $3^{3.5}$ and the propaganda of family values and motherhood through inult imitres and articles printed in the press. This 
pronatalist and pro-family propaganda says lictle about men helping relieve women's burden in the home and is of uncertiain effectiveness. 126 More signiflcant and steadily growing in popularity has been the Family Service network of rudinentary counselling offlces and get-acquainted services, which have spread across the country since the suggestions of the sociologist, Iuri Rlurikov, sparked them in the early 1970s.127 All in all, taken along with such measures and exlsting programs of soclal security and family assistance, 128 the pronatalist polıcy of the early 1980s adds up to a broad but modest commitment to birth stimulation.

During the long and heated debate leading up to this policy, the late Boris Urlanis pointed out to his fellow demographers, and in effect to the regime he adviset, that maintaining any future "optimal" birthrate would require making it in the interests of parents to do so. 129 Concerned that the birthrate was slipping below optimum, the regime has felt compelled to cater to those parental interests. The result is a carefully balanced and modest ramoromse between commutment and frugality. "Understandably," said the General secretary," we cannot do everything at once."130 It compramises also between differentation by region (and often cherefore nationality) and exylul rreatment between quantitative, cash benefits and qualitative steps to improve the environment of the f.dinily. Allowances are so modest as to be far wershadowed by increases in pensions--by seven times in 1.381. 131 Even the linited cash benefits are only as good as the purchasing power of the ruble, and that is shaky in the light of the sinortages of legally avarlable goods and services outslitie the black market. 132

The whole thrust of the policy is well stated in the party Gurdelines: "to create optimum condltions for women to combine notherhood with an active working career." Nowhere do chey say "to enable parents to combine parenthord 
with an active working career;" nor does it emphasize the importance of husbands' helping their wives. In that sense the main thrust of policy has been consistent since 1917.

Epilogue:

The successor administration to Brezhnev's continues to reaffirm the family's indispensable demographic role. A new mass-circulation Short Popular Dictionary-Handbook on Marriages and the Family, written by Alexandra Pergament, the eminent family law specialist and published during Andropov's reign, asserts that "the family is the primary unit of society. Without it society itself cannot exist. The bearing and upbringing of children - the future members of society, creators of its material and spiritual culture -occurs in the family. In socialist society, this is the basic function of the family." This handbook, published in 100,000 copies by the Znanie society as a means of public education in law, reaffirms the population policy adopted in 1981.133

Looking ahead, both Western and Soviet demographers project further drops In population growth, a possible population decrease by the next century, as well as large increases in the percentage of the least urban and assimilated, mainly Moslem, nationalities. 134 Also, one sees no immediate end to the issue of how much or little to continue favoring Central Asians and inhabitants of the republics of the Caucasus. The demographic program of the Soviet government enacted in the early 1980s falls short of the regional differentiation advocated in 1978 by Litvinova, whom we cited earlier as a participant in the debate over demographic policy. After the new policy was enacted, Litvinova teamed up with the demographer Urlanis to defend an even more radical differentiation than either of them had advocated before the enactment of the new demographic program. 
Litvinova and Urlanis added to their earlier proposals for favoring regions of low fertility (as a part of a demographic policy) the new demand to end alleged preferential budgetary allocations and tax benefits, and to switch agricultural procurement prices from the high-fertility "border republics" of Central Asia and the Caucasus, which they see as over-privileged areas of low out-migration and a work force largely unavailable or unsuitable for the modern industrial sector of the Soviet econamy, to the neglected and "more needy central regions, above all the non-Black Earth Region" of the Russian Republic. 135 Demographically, this set of demands carries on Litvinova's earlier proposal for "not the maximum number of children in certain families (of national regions)" but "the minimum number of children in the majority of families over the entire territory of the Soviet Union."136 Politically and economically, this set of demands for redistribution away fram the fertile border republics and toward the Russian heartland reflects a deeper issue of development policy in a multi-national country. It would seem that the issue of how much to discriminate against minority nationalities in family payments and developmental policy is far fram settled within the govermment. Were it settled the article just cited would have been unlikely to appear. Whether or not the writers had any links with Russian nationalist sentiment in ruling circles, "Russianism" will keep alive such views as those expressed by Litvinova and Urlanis. 137 Mass migration from the Central Asian republics would relieve pressures on birth stimulation and help to defuse the issue of regional priorities, but this solution based on the evidence at our disposal is unlikely in the near future. 138

Conclusion:

As Soviet families have grown smaller and shakier, a wider gap has opened between the "interests of the family" and the "interests of the state." 
Comparisons between soviet and "bourgeois" families have given way in part to more sambre and searching reflection on the "problems" and "complications" besetting families' performance of the demographic roles which the goverment expects of them.

Recent legal reforms have increased legal intervention to enforce the protection of needy; pregnant and nursing spouses and to increase the responsibilities of their partners, as well as to bend cammity property away from equal shares when this benefits the needy or more deserving spouse. The easing of divorce procedures is a compramise between the full freedam of the 1920s and the obstacle course of the years 1944 to 1965 . While divorce is easier, marriage has been made harder by longer witing periods and by possibilities for invalidating "fictitious marriages" of convenience. Thanks to the present reformed law; about half of the unwed mothers may hope for at least legal equality for their children and the extra-marital fathers of their children. Gone is the stigma of illegitimacy fram the birth certificates of all extra-marital children. But again, as with divorce, there were compromises, which greatly limit the grounds for paternity suits.

The goverment's return to an active pronatalist policy after nearly three decades entails a moderate birth stimulation package hedged by many compromises--between paying mothers to stay home and have children and making it easier for them to get back to work; between a regionally differentiated allocation of benefits and equal treatment of all regions and nationalities; between financial camitment to birth stimulation and the funding of campeting programs ranging fram pensions and medical care to agriculture and defense.

Policy is not the only thing to change in the relationship between goverment and 'family since Stalin. The goverment's approaches and perceptions have changed. It turns much more than before to the experts in 
law; sociology; demography, and other family-related fields, and cautiously drafts legislation only after much debate among the advisers, rather than abruptly by fiat. Similar changes in policy-making have occurred in the Soviet system generally. 139

The regime's approach in family policy has become less compulsive. It indicates an awareness of the complexities and limitations of manipulating families, even if by the most powerful governmental apparatus in the world. Because of the empirical limits on compulsion and the government's demographic needs, the family has gained leverage, so too have women within the family, despite their lack of any autonomous feminist organizations and spokespersons.

Drives for worker and administrative discipline initiated under Andropov showed more determination than had been the case under Brezhnev. They reportedly brought immediate gains of higher labor productivity. But if these gains prove to be one-shot outcomes of the tightening of work penalties and controls, and if economic reforms do not soon come to pass which will permanently increase the efficiency of labor utilization in the USSR, 140 or if the government does not find a way soon to utilize effectively the surplus rural populations of Central Asia, then the government will have to continue to recognize, as it does at present, the need to pay greater heed to the interests of the family in pursuit of its own.

A return to imposing its interests on the family through abortion bans and tighter divorce rules is not likely. But were some Soviet government to decide to bring to the family the drive for discipline it brought to the workplace, a solution to demographic problems is unlikely. The huge, oppressive power of the KGB and the extreme centralization and massive apparatus of the Soviet regime tend to conceal the other side of this 
dialectic of power. By their sheer complexity and change, Soviet society and the Soviet economy, together with soviet nationalities and the diverse interests among the ruling elites of the USSR, place limits on the emergence and triumph of a single will able to redirect the behavior and motivations of Soviet people and Soviet families $r$ : $k$ toward the lost era of the "revolution from above." It is not only that the government needs women at the workbench and desk as much as by the cradle. It is also that the government must know from past experience that as rigid laws against entrepreneurial choice brought the "second econany," so would rigid laws against marital and reproductive choice in the family bring more evasion and a "second demography"--a furtive and evasive exercise of free choice in marriage, divorce, and child bearing at unfathomable social and medical costs. 


\section{FOOTNOTES}

1. "Fundamentals of Legislation on Marriage and the Family of the USSR and Union Republics," June 27, 1968, "Preamble." (Hereafter, "Fundamentals") Same later portions of the text were revised October 9, 1979. Vedomosti Verkhovnogo Soveta SSSR, 27 (1968), item 241, and 42 (1979), item 696. (Hereafter, Ved. V. S. SSSR.)

2. Rudolf Schlesinger, Changing Attitudes in Soviet Russia: The Family in the USSR (London: Routledge and Keegan Paul, 1949), 169-71; S. Frederick Starr, "Visionary Town Planning During the Cultural Revolution," in Cultural Revolution in Russia, 1928-1931 (Bloomington, Ind.: Indiana University Press, 1978), 207-40; G. D. Andrusz, "Housing Ideals, Structural Constraints and the Emanclpation of Women," in Hame, School and Leisure in the Soviet Union, ed. by Jenny Breen, Maureen Perrie and Andrew Sutton (London, George, Allen \& Unwin, 1980), 3-12; Peter H. Juviler, "Soviet Families," Survey (July 1966), $51-55$

3. A. G. Kharchev, Brak 1 sem'ia v SSSR (2nd ed.; Moscow; Mysl', 1979), 352-63.

4. B. Ts. Urlanıs, Problemy dinamiki naseleniia SSSR (Moscow: Nauka, 1974), 299-300.

5. Kharchev, Brak i sem'ia, 74-5.

6. Vera Tkachenko, "Ne otrekis" ...," Pravda, February 9, 1982. See also N. Loginova, "Pokidysh," Literaturnaia gazeta, March 23, 1983. (Hereafter, $\underline{L G}$ )

7. Konstitutsiia (osnovnoi zakon) Soiuza Sovetskikh sotsialisticheskikh respublik. (Moscow: Iuridicheskaia literatura, 1978).

8. Kharchev, Brak i sem'ia, 50 (emphasis added). 
9. H. Kent Geiger, The Family in Soviet Russia (Cambridge, Mass.: Harvard University Press, 1968), 193-98; Barbara Wolfe Jancar, Wamen under Communism (Baltimore: Johns Hopkins University Press, 1978), 71-72; V. A. Borisov, Perspektivy rozhdaemostl (Moscow: Statistika, 1976), 166-76; A. A. Popov, "Medical-Demographic Reasons and Factors for Abortion," Zdravokhranenie rossiiskoi federatsii, 9 (1980), 27-31, transl. in JPRS \#78047.

10. Peter H. Juviler, "Family Reforms on the Road to Communism," in Soviet Policy-Making: Studies of Communism in Transition, ed. by Peter H. Juviler and Henry W. Morton (New York: Praeger, 1967), 29-60.

11. Edict of December 10, 1965, Ved. V.S. SSSR, 49 (1965), item 275.

12. Narodnoe khoziaistvo SSSR v 1979 godu (Moscow: Statistika, 1980), 35; Narodnoe khoziaistvo SSSR v 1980 godu (Moscow: Statistika, 1981), 30.

13. Communique and decree of April 8, 1968., Ved. V.S. SSSR, 16, (1968), 230, 234; Izvestila, April 10, 1968.

14. "Fundamentals," article 14, parts 2,3,5. The "Fundamentals" received detailed elaboration, with some local differences, in the Family Law codes of the 15 Union republics passed in 1969 and 1970. The latest version of the RSFSR code consulted here comes with commentary and is referred to here as Komentarii. Kammentarii $k$ kodeksu 0 brake $i$ sem'e RSFSR (Moscow: Iuridicheskaia Literatura, 1982). A description of the passage of the Fundamentals and codes is in Peter H. Juviler, "Whom the Law has Joined: Conjugal Ties in Soviet Law," in Soviet Law after Stalin. Part I: The Citizen and the State in Contemporary Law, ed. Donald D. Barry, George Ginsburgs and Peter B. Maggs (Leyden: A. W. Sijthoff, 1977), 124-27.

15. See, Ibid., n. 24, 152 on discussion and on "Fundamentals," Pravda and Izvestiia, June 28, 1968; Ved. V.S. SSSR, 27 (1968), item 241 .

16. Schlesinger, Changing Attitudes, 154-168. 
17. "Fundamentals," article 14, part 7.

18. Narodnoe khoziaistvo 1979, 35.

19. For a discussion of Brezhnev's approach to policy see George W. Breslauer, Khrushchev and Brezhnev as Leaders: Building Authority in Soviet Politics (London: George Allen and Unwin, 1982).

20. V. A. Riasentsev, Semeinoe pravo (Moscow: Iuridicheskaia Literatura, 1971), 22 .

21. "Fundamentals," article 16, part 1.

22. Kommentarii, 98-99, 227-28; "Fundamentals," article 16, part 2.

23. "Fundamentals," article 17, part 1.

24. "Fundamentals," article 17, part 3; Kosmentarii, 100-101.

25. "Fundamentals," article 16, part 4.

26. I. Grishin, "Sudebnaia ekspertiza po delam ob ustanovlenii otsovstva," Sotsialisticheskaia zakonnost', 3 (1975), 67.

27. S. Bratus', E. Fleishits, and A. Pergament writing in Izvestiia, May 7, 1968 .

28. Ibid.

29. Izvestiia, June $28,1968$.

30. Peter Juviler, "Marriage and Divorce," Survey, 48 (July 1963), 11213.

31. M. V. Materova, Sudebnoe rassmotrenie del ob ustanovlenii otsovstva (Moscow: Iuridicheskaia Literatura, 1972), 73-74.

32. Ibid., 73.

33. Juviler, "Whom the Law Has Joined...," 142.

34. Examples of such proof are absent at possible time of conception and infertility. Kammentarii, 97.

35. Izvestiia, June $28,1968$. 
36. A. Beliavskii; "Ostorozhno-zakon!" LG, April 26, 1967; William M. Mandel, Soviet Women (Garden City, N.Y.; Anchor Books, 1975), 231; M. Tol'ts, "Kharakteristika nekotorykh kamponentov rozhdaemosti $v$ bol'sham gorode," in Demografisheskii analyz rozhdaemosti, ed. D. I. Valentei (Moscow: Statistika, 1974), 46-51.

37. Juviler, "Whom the Law Has Joined...," 128-31.

38. "Fundamentals," article 13, parts 1-2; Kammentarii, 59.

39. Kammentarii, 60 .

40. Juviler, "Whan the Law Has Joined...," 130.

41. "Fundamentals," article 19, part 1.

42. Peter H. Juviler, "Law and the Delinquent Family," in Soviet Law after Stalin. Part II. Soclal Engineering Through Law, ed. by Donald D. Barry, George Ginsburgs, and Peter B. Maggs (Alphen an den Rijn, the Netherlands: Sijthoff and Noordhoff, 1978), 224-25.

43. I have dealt with all this in detail in "The Urban Family and the Soviet State," in The Contemporary Soviet Clty, ed. by Henry W. Motron and Robert Stuart (Armonk, NY: Sharpe, 1984); and "The Soviet Family in PostStalin Perspective," in The Soviet Union Since Stalin, ed. by Stephen F. Cohen, Alexander Rabinowitch and Robert Sharlet (Bloamington, Ind.: Indiana University Press), 228-240. See also, for example, Sar A. Levitan and Richard E. Belous, What's Happening in the American Family? (Baltimore: Johns Hopkins University Press, 1981); Marilyn Rueschemeyer, Professional Work and Marriage: An East-West Comparison (New York: St. Martin's Press, 1971); Naomi Black and Ann Baker Cottrell, Wamen and World Change: Equity Issues in Development (Beverly Hills: Sage Publications, 1981). 
44. A. Velikanova, Z. Balaian, "70 millionov semei," LG, October 26, 1983. The figures here are for families under the census definltion of relatives living together and sharing a common budget. Generally I use "family" here to include the census family plus members living apart but sharing a common budget -- which I take to mean students, prisoners, servicemen and wamen, persons living at separate addresses temporarily while waiting for housing together.

45. Narodnoe khozlaistvo 1979, 35.

46. A. G. Volkov, "Sem'ia kak faktor izmeneniia demograficheskoi situatsii," Sotsiologicheskoe issledovaniia, 1 (1981), 35. (Hereafter SI) Adult male mortality comes close to divorce as a factor in the break-up of famrlies. Ibid., 29.

47. Alexander I. Smuronv of Gosplan is reported to have given (in 1981) Infant mortallty figure for the USSR since 1978 of about 28 per thousand infants not living to the age of one year. This compares with rates of 13 or 14 per thousand in the U.S. at the time, and in 1977 or 1978 in other countrıes: France, 11.4, West Germany, 15.5, Britain, 14.0, Sweden, 7.7, Japan, 8.9. Very high rates among the rural population of Central Asia ralses the Soviet race; but in the absence of detailed data, we cannot now say by how much. Serge Schemann in The International Herald Tribune, June 23, 1981 and The New York Times, June 21, 1981. Mlchael Binyon in The Times of London, June 12, 1981, reported Mr. Smirnov as giving an infant mortality figure of 30 per thousand. As it is, the Soviet figures should be increased by 14 percent to allow for Soviet non-counting of most prematurely born bables in the mortality figures. Christopher Davis and Murray Feshbach, Risıng Infant iortality in the U.S.S.R. (Washington, D.C.: U.S. Dept. of Commerce, Bureau of 
the Census, Foreign Demographic Analysis Division, September 1980), 3-6, 23. 48. Juviler, "Marriage and Divorce," 104-17; Narodnoe khozlaistvo 1979, 35.

49. See note 12 above.

50. Kharchev, Brak i sem'ia, 221 .

51. Iurii Riurikov, "Sila domashnogo œhaga," LG, February 11, 1981.

52. G. Sarkisyan, "What Does Well-Being Mean to the Soviet People?" Nauka i zhizn', 12 (1981), transl. in Reprints from the soviet Press, February 15, 1982, 22. See also, e.g., Kharchev, Brak i sem'ia, 221; "Vazhnaia problema sovetskoi sotsiologicheskol nauki," SI, 2 (1979), 3-5.

53. Peter H. Juviler, "The Urban Family and the Soviet State"; E. L. Manevich, Voprosy Truda V SSSR (Moscow: Statistika, 1980), 99-100; Sarkisyan, 21.

54. O. Ata-Mirzaev and B Gol'dfarb, "Perspektivy vosproizvodstva naseleniıa srednei azii," in Nashe budushchee glazami demografa, ed. D. I. Valentei (Moscow: Statistika, 1979), 117; I. Bestuzhev-Lada, "Skol'ko nas na zemle," in "Shagı k semeinamu schast'ıu," Nedelia, 3 (1982), 19; David Heer, "Soviet Population Pollcy:: Four Model Futures," in Soviet Population Policy: Conflicts and Constraints, ed. Helen Desfosses (New York: Pegamon, 1981), 13839; Alfred J. Di Malo, Jr., "Contemporary Soviet Population Problems," Ibid., 27; Michael Rywkin, Moscow's Moslem Challenge: Soviet Central Asia (Armonk, NY: Sharpe, 1982), 64, 69-80.

55. Sarkisyan, 21 .

56. Itogi vsesoiusnoi perepısı naseleniia 1970 goda. IV (Moscow: Statıstika, 1973), 11-15; Naseleniia SSSR po dannym vsesoiuznoi perepisi naseleniia 1979 goda (Moscow: Statistika 1980), 27-30. 
57. D. Valentei, "Ot rozhdeniia do stareniia," in "Shagi $k$ semeinomu schast'ia".

58. Sar A. Levitan and Richard S. Belous, What's Happening to the American Family? (Baltimore, 1981), vii-viii.

59. Kenneth Keniston and the Carnegie Council on Children, All our Children: The American Family under Pressure (New York: Harcourt Brace Jovanovich, 1977); Gilbert Y. Steiner, The Futility of Family Policy (Washington, D.C.: The Brookings Institution, 1981).

60. A. Severina, "...No sem'iannam byt' obiazan," in "Shagi $k$ semeinamu schast'iu".

61. Footnote citations for Chapter 2 of A. G. Karchev's Brak i sem'ia v SSSR (lst ed., Moscow Mysl', 1964); "The Social Significance of Marriage and the Family," had 7 of 43 Western sources (other than Marx, Engels and Hegel). The second edition (1979) of Kharchev, Brak 1 sem'la had 21 out of 55 cited Western sources, a large increase.

62. Ibid., pp. 344-45; G. K. Matveev, Sovetskoe semeinoi pravo (Moscow: Iurldicheskala Literatura, 1978), 41-42 on a family of a "newer, higher type."

63. Kharchev, Brak i sem'1a, 19, 21, 94-120, 175-77.

64. Ibid., 28-9, 365-66.

65. Ibid., 3, 77-121, 266-67; USSR Constitution, preamble and Article 6; see also note 61 .

66. Kharchev, Brak I sem'ia, 3.

67. Ibld., 66-75, 166-67, 174-82, 228-32; E. K. Vasil'eva, Obraz zhizni gorodskoi sem'i (Moscow; Financy I Statistıka, 1981), 4; T. V. Riabushkın and R. A. Galetskala, Dinamıka i struktura naseleniia v sotsialisticheskom obshchestve (Moscow: Statistika, 1979), 211. 
68. The closest to an exception to this rule might be I. S. Kon, "O sotsiologicheskoi interpretatsıl seksual'nogo povedeniia," SI, 2 (1982), 11322.

69. For example, Vasileva, Obraz zhizni, p. 3; the oblique mention of the impact of Stalin's collectivization in Kharchev, Brak i sem'ia, (1964), 160 is missing entirely from the 1979 edition

70. B. Ts Urlanis, Rozhdaemost' $i$ prodolzhitel'nost' zhizni $v$ SSSR (Moscow: Gosstatizdat, 1963), 48.

71. Helen Desfosses, "Demography, Ideology, and Politics in the USSR," Soviet Studies, 2 (April 1976), 246.

72. Urlanis, Rozhdaemost', 133; I. Iu. Pisarev, Naselenie SSSR (Moscow: Gosstatizdat, 1962), 176.

73. It predlcted 280 million inhabitants by $1980,15.5$ million too high.

74. Narodnoe khozlaistvo SSSR V 1963 goda (Moscow: Statistika, 1965), 103; Narodnoe khoziaistvo SSSR V 1967 godu (Moscow: Statıstika, 1968), 41, 179; Urlanis, Rozhdaemost', p. 133; Narodnoe khozialstvo 1979, 7.

75. The CPSU in a resolution on the social sciences called for "social and economic research in the field of demography." Kormunisticheskaia partiia sovetskaia soiuza $v$ rezoliutsilakh I resheniiakh s"ezdov, konferentsii i plenumov TsK. IX, 1966-1968 (Moscow: Izd. polit. lit., 1972), 348-9; T. V. Riabushkin, ed., Izuchenie vosprolzvodstvo naselenıe (Moscow: Nauka, 1968), especially Ia. N. Guzevatı, "Aktual'nye problemy narodonaselenie v sovetskom ekonomike," 9-22; V. Perevedentsev, "Zdravyi smysl Ili nauchnoe znanie: Avtor ubezhden; bez eksperimental'nol proverki teoretisheskikh polozhenil davat' demograficheskie rekomendatsii nel'zla," LG, June 10, 1968; V. Perevedentsev, "Prodolzhenie spora," LG, April 26, 1968; John F. Bessemeres, Socialist Population Policies: The Political Implications of Demographic Trends in the 
USSR and Eastern Europe (White Plains, NY: Sharpe, 1980), 95-103; Helen Desfosses, 248-51.

76. Soviet census takers ignored demographers' request to ascertain female fertility (with the question, "How many children have you borne?") in 1959 and 1970 (V. Perevedentsev, "Ractem ot god k godu my..." IG, October 3, 1979), but not in 1979, Vestnik statistiki, 2 (1981), 62. (Hereafter VS) Overall, though, 1979 census results are skimpier, with more delays in publication, than in 1959 and 1970. Murray Feshbach, "Development of the Soviet Census," in Soviet Population Policy, 3-15. Same of those demographic statistics with unfavorable turns have ceased to appear; e.g., life expectancy by sex after 1971-72, infant mortality after 1974, age specific mortality after 1975-1976, rates of natural reproduction (number of daughters to be expected to be born and live to age of mother when they were born) after 197576. Narodnoe khoziaistvo SSSR v 1972 godu (Moscow: Statıstika, 1973), 564; Narodnoe khoziaistvo 1979, 430; VS, 12 (1975), 84; VS, 12 (1977), 74; David M. Heer, "Population Policy," in Contemporary Soviet Society: Sociological Perspectives, ed., Jerry G. Pankhurst and Michael Paul Sacks (New York: Praeger, 1980), 82-83.

77. Heer, "Soviet Population Policy", 124-50; Helen Desfosses, "ProNatalism in Soviet Law and Propaganda," Ibid., 95-117; Di Maio, Ibid., 31-37.

78. G. Litvınova, B. Ts. Urlanis, "Demograficheskaia polıtika sovetskogo gosudarstva," SGiP, 3 (1982), 39.

79. Heer, "Population Polıcy", 84-5 and "Soviet Population Policy", 14445. 149-50; Desfosses, Soviet Population Policy, xviii-xx.

80. A. G. Volkov, "Sem'ia kak faktor izucheniia demograficheskoi situatsii," SI, 1 (1981), 42; "Mezhditsiplinarnye issledovaniia sem'i," SI, 2 (1982), 80; Litvinova and Urlanis, "Demograficheskaia politika", 38. 
81. Desfosses, "Pro-Natalism", 99; Perevedentsev, "Zdravyi smysl...; "Pravovye aspekty demograficheskol politikı," SGlP, 1 (1975), 32-33. The closest to printed approval of an abortion ban are remarks on the ban in the USSR, (1936-55) and in Eastern European communist countries: "These measures over several years has a certain effect of raising the birthrate, or, at least, dıd not allow lts sharp decline." Rlabushkın and Galetskaia, Dinamika, 212.

82. Jeffrey W. Hahn, "Soviet Demographic Dilemmas," Problems of Communism (September-October 1981), 56-61; Heer, "Soviet Population Policy", 130-50.

83. A. G. Volkov, "O neobkhodimosti vozdeistvila na rozhdaemost'," in Roshdaemost': problemy isucheniia, ed. L. E. Darskii (Moscow: Statistika, 1976), 47. See also, A. G. Vishnevski1, "Tendentsil rozhdaemosti i problemy lzuchenila $3 k h$ posledstvil," in Ibid., 22-34; A. G. Vishnevskii, "Demogaflcheskala polıtıka 1 demograflcheskil optımum," in V. S. Steshenko and V. P. Piskunov, Demograficheskaia polıtıka (Moscow: Statistika, 1974), 69-80; A. G. Vishnevskıl, "Demogratıcheskaia revoliutsıla i budushchee rozhdaemosti i smertnosti V SSSR," in Nashe budushchee glazami demografa, ed. D. I. Valentel (Moscow: Statistika, 1979), 31-43.

84. Volkov, "O neobkhodimosti", 47.

85. A. G. Vishnevskil in Demograflcheskala revoliutsila (Moscow: Statıstika, 1976), quoted in Hahn, "Soviet Demographic Dilemmas", 59-60.

86. Volkov, "O neobknodimostı", 44.

87. D. Valovol, 르 al., "Give Impetus to the Shchekino Method," Pravda, June 14, 1982, condensed in Current Digest of the Soviet Press, 24 (July 14, 1982), 10-12. (Hereafter referred to a CDSP.)

38. "Ruchnoi trud - na plechı machin," Pravda, April 9, 1982. 89. See note 82 . 
90. Desfosses, Soviet Population Policy, xv-xvili; Perevedentsev, "Prodolzhenıe spora"; Population Policy, 72; B. Ts. Urlanis, Problemy dinamiki naselenıia SSSR (Moscow: Statıstika, 1974), 271.

91. Richard Bessel, comp., Current Soviet Policies VI. The Documentary Record of the 24th Congress of the Communist Party of the Soviet Union (Columbus, Onıo: AAASS, 1973), 26.

92. Pravda, February 25, 1976.

93. A. Ya. Kvasha, Upravlenie razvitiem narodonaseleniia V SSSR: prospekty i perspekıtvy (Moscow: Statistıka, 1977), 3; V. Perevedentsev, "Narodonaselnıe i demograficheskaia politıka partıi," Politicheskaia samoobrazovanie, $8(1981), 45$, etc.

94. Pravda, October 26, 1976.

95. "Pravovye aspekty...", 23; D. I. Valentel, "250,000,000: kammentariı, problemy, prognozy,' reprinted in G. P. Kiseleva, Demografi dumaiut, sporiat, sovetuiut (Moscow: Statıstıka, 1981), 43.

96. Riabushkin and Galetskaia, Dinamnka, 219-21.

97. Ibld., 202-203, 208; N. K. Morozova, "Problemy vsaimnosviazi zanlatnosti zhenshchin i rozhdaemostı," in Demografiia i ekonologiia krupnogo goroda, ed. N. A. Tolokontseva and G. M. Romankova (Leningrad: nauka, Leningradskoe Otdelenie, (1980), 7C; Z. Iankova, "Zhenshchina na rabote i doma", LG, March 5, 1980; A. G. Kharchev, M. S. Marskovskıi, Sovremennala sem'ia i problemy (Moscow; Statistika, 1978), 1-4, 155-62.

98. L. E. Carskii, ed. Skol'ko detel budet v sem'e? (Moscow: Statistika, 1977), passim.

99. Steshenko and Piskunov, Demograficheskaia politika; Heer, "Soviet Population Polıcy", 140-42. 
100. R. A. Lewis and A. J. Jaffe, "Birth Rates in the U.S. and the USSR Over the Last Half Century - Some Observations," presented at the annual meetıng, Populatıon Association of America, 1967; A. I. Antonov, Sotsıalogiia rozhdaemostl (Moscow: Statistika, 1980); Jeffry Chinn, Manipulating Soviet Population Resources (New York: Sharpe, 1977), 70-77.

101. "Pravovye aspekty...," 24, 31; V. Perevedentsev, "Edinstvennyi v sem'e," LG, March 16, 1977; Heer, "Population Policy", 77; Hahn, "Soviet Demographic Dilemas", 57-8.

102. Urlanis, problemy dinamiki naseleniia, 288; Chinn, 68-9.

103. Valentei, "250,000,000", 34.

104. E. L. Manevich, Voprosy truda V SSSR (Moscow: Statistika, 1980), 101.

105. Elızabeth E. Bacon, Central Asians under Russian Rule: A Study in Culture Change (Itnaca: Cornell Unıversity Press, 1966), 214-16; Rywkin, 71, 85-86, 117-18, 150-53; Helene Carrere d'Encausse, Decline of an Empire (New York: Newsweek Books, 1979), 227-64; Teresa Rakowska-Harmstone, "The Study of Ethnlc Nationalities in the USSR," in Nationalism in the USSR and Eastern Europe, ed. George W. Simmons (Detroit: Unlversity of Michigan Press, 1977), 21 and "Nationalism in Soviet Central Asıa since 1964," Ibld., 272-94.

106. Bessemeres, Soclalist Population Policy, 57-83; Heer, "Soviet Population Policy", 137-50; "Polozhenle proftekhshkoly, Pravda, August 2, 1982.

107. Rywkın, 71.

108. Manevich, Voprosy truda, 108.

109. A. Zaravomyslov, "Sotsial'naia politıka KPSS 1 natsional'nye otnoshenıia," Pravda, August 27, 1982. 
110. Manevich; Voprosy truda, 108-109; V. I. Perevedentsev, "Vosproizvodstvo naseleniie sem'e," SI, 2 (1982), 80-88. "In this connection," says Manevich (109-110) "one should keep in mind the answer of L. I. Brezhnev to the correspondent of the French newspaper, Le Monde. Asked, "Do you not think that an accelerated growth of the populaton in the national republics may entail certain structural changes?" L. I. Brezhnev answered, "The growth of the population in one republic or another does not disturb us. On the contrary, it gladdens us."

111. Riabushkin and Galetskaia, Dinamika, 205-206. The arguments are about quality - health care, infant mortality, type of upbringing.

112. See also Urlanis, Problemy dinemiki naseleniia, 303.

113. G. I. Kitvınova, "Vosdeistvie gosudarstvo i pravo na demograficheskıe protsessy," SGiP, 1 (1978), 135; Heer, "Soviet Populatıon Policy", 132-3.

114. Litvinova, "Vosdelstvie gosudarstvo", 136.

115. Pravda, March 5, March 31, September 6, 1981.

116. Pravda, February 24, 1981.

117. Pravda, March 5, 1981.

118. This is a tax on men aged $21-49$ and women $21-39$, other than single women and widows, who earn 70 or more rubles a month, at a progressive rate rising to a plateau of 6 percent of salary at 90 rubles or more a month. F. J. M. Feldbrugge, Encyclopedia of Soviet Law, vol. I (Dobbs Ferry, NY: Oceana Publications, 1973), 662.

119. Edict of September 25, 1974. It provides for an allowance of 12 rubles a month for each child up to 7 years old when per capita income is below 50 rubles. Ved. V.S. SSSR, 40 (1974), 1tem 63. 
120. Sergei Voronitsyn, "Interest-Free Loans for Young Couples in the USSR," RL, 156/82 (April 7, 1982), 1-2.

121. Pravda, August 26, 1982.

122. Arkadii Vaksberg, "Courtroom Sketch: Break," LG, June 3, 1981, abstract in CDSP, 18 (June 3, 1981), 3-4; M. S. Bednyl, Medikodemograficheskoe izuchenie narodonaseleniia (Moscow; Statistika, 1979), 78; E. S. Demidenko, Demografisheskie problemy i perspektivy bol'shikh gorodov (Moscow: Statistika, 1980), 118-19.

123. Bednyi, Mediko-demograficheskoe.

124. Severina, "... No sem'ıannom byt" ".

125. Marriage, birth registration and other ceremonies for families aim at strengthening family ties while replacing traditional, conservative relıgous ceremonies. V. A. Rudnev, Obriady narodnye i obriady tserkovnye (Leningrad: Lenizdat, 1982); M. N. Kulazhnikov, Pravo, traditsii 1 obychai (Rostov: Izd. Rostovskogo Universiteta, 1972).

126. Desfosses, "Pro-Natalism".

127. Iu. Riurikov, "Liubov i sem'ia segodnia ostrye I spornye voprosy," Molodoi kommunist 10 (1975), 88-89; Yelena Muskina, "Great Expectations," Zhurnalist, 12 (December 1978), abstract in CDSP, 8 (March 21, 1979), 12-13; "Solving Soviet Famrly Problems: Divorce, Remarriage, and Alienated Youth," excerpted from Nedelia, January 12-18, 1981 in World Press Review (April 1981), 35; Volkov, "O neobkhodimostı", 40.

128. Heer, "Soviet Population Policy", 125-28.

129. Urlanıs, problemy dinamiki naseleniia, 218, 306.

130. Pravda, February 24, 1981.

131. Narodnoe khoziaistvo SSSR 1922-1982 (Moscow: Flnansy i statistika, 1982), 419 . 
132. Sarkisyan, "What Does Well-Being Mean", 14; a sign Soviets are aware of this.

133. A. I. Pergament, Kratkıi popularnyi slovar'-spravochnik o brake i sem'e (Moscow: Znanie, 1982), 29. See also Ved. V.S. SSSR, 5 (1983), item 74. 134. Murray Feshbach, "Between the Lines of the 1979 Census, Problems of Communism, (January-February 1982), 35-36; Stephen Rapawy and Geoffry Baldwin, "Demographic Trends in the Soviet Union: 1950-2000", in Joint Economic Committee, Congress of the United States, Soviet Economy in the 1980s: Problems and Prospects (Washington, D.C.: U.S. Govt. Printing Office, 1983), 265-96; Murray Feshbach, "Trends in the Muslim Population-Demographic Aspects," Ibid., 297-322; "Rod Liudskil: skol'ko nas budet," LG, January 28, 1976; Antonov, Sotsialogiia rozhdaemosti, 263-64; Perevedentsev, "Voproizvodstvo", 80-88.

135. Litvinova and Urlanis, "Demograficheskaia polıtika sovetskogo gosudarstva," $38-48$.

136. Litvinova, "Vosdeistvie gosudarstvo", 135.

137. Edward Allworth, ed., Ethnic Russia in the USSR: The Dilerma of Daminance (New York: Pergamon Press, 1980); Davıd K. Shıpler, Russia: Broken Idols, Solemn Dreams (New York: Times Books, 1983), 326-46; Alexander Yanov, The New Russian Right: Right-Wing Ideologies in the Contemporary USSR (Berkeley, Cal.: Institute of International Studies, 1978).

138. Seweryn Bialer, Stalin's Successors: Leadership, Stability and Change in the Soviet Unzon (New York: Cambridge University Press, 1980), 290296; text of this paper, 16-17. Large-scale migrations from Central Asia to labor-short areas are not in prospect, and if they were, would have many drawbacks in efficiency. Ann Goodman and Geoffry Schliefer, "The Soviet Labor 
Market in the 1980s", in Joint Economic Committee, Congress of the United States, Soviet Economy in the 1980s: Problems and Prospects, 332-333.

139. Blaler, Stalin's Successors, 69-96; Jerry Hough, Soviet Leadership in Transition (Washington, DC: The Brookings Institution, 1980).

140. (a) Under Brezhnev, the government had undertaken to tighten labor discipline and improve economic organization but without visible success. (b) The pace of the drive increased under Andropov, but in discipline and control of labor much more emphatically than in the very limited and cautious efforts at reform, in the context of which further efforts at technical modernization must be hampered. (c) Same well-placed Soviet economists call the present system outdated and a cause of indiscipline rather than simply suffering from indiscipline. Long term prospects without further reform are for continued labor shortages for a long time to come. (a) "Sovershenstvovat' upravlenie ekonomiki" (on non-fulfillment of Brezhnev reform decress of 1979). Pravda, March 17, 1983; Goodman and Schliefer, "The Soviet Labor Market...," 336-39; Joseph S. Berliner, "Managing the Soviet Economy: Alternative Models," Problems of Communism, I (January-February 1983), 40-56. (b) CPSU decree on law and order, Pravda, September 11, 1979; 1ncreases in administrative and criminal penalties for violations and misappropriations: Edict of July 26 , 1982, Ved. V.S. SSSR, 30 (1982), item 572; revisions to the criminal code of the R.S.F.S.R., October 11, 1982. Ved. V.S. RSFSR, 4 (1982), item 1513; Edict of October 15, 1982 (crackdown on "parasites" etc.), Ved. V.S. SSSR, 42 (1982), item 793, 794; speech of Andropov, Pravda November 23, 1982; law on labor collectives of June 17, 1983, Ved. V.S. SSSR, 25 (1983), item 382; Decree of the C.C. of the C.P.S.U. and Councll of Ministers of the USSR on increasing the economic authority of production associations and enterprises, Pravda, July 26, 1983; Decree of the C.C. of the C.P.S.U., USSR Council of 
Ministers and All Union Central Council of Trade Unions on strengthening labor discipline; adding and increasing penalties and adding restraints on job changing; Pravda; August 7; 1983; decree on accelerating scientific and technical progress; Pravda; August 28; 1983; (c) "Excerpts from the Soviet Study on the Need for an Overhaul of the Econamy;" The New York Times; August 5; 1983; the longer and purported original version of the critical report with even more emphasis on the limits of disciplining in an outdated economic system which is the real problem: Radio Svoboda; Arkhiv Samizdata; Materialy Samizdata; 35/83; August 26; 1983; AC No. 5042, "Tat'iana Zaslavskaia; zav. otdelom sotsial'nykh problem IEiOPP SO AN SSSR. Doklad o neobkhodimosti bolee uglublennogo isucheniia v SSSR sotsial'nogo mekhanizma razvitiia ekonomiki, sostavlen; veroiatno; $\mathrm{v}$ Akademgorodke; Novosibirsk; predstavlen na nauchnom seminare v Moskve; aprel' 1983." Quarterly plan fulfillment reports Pravda, January 23, April 24; July 23, 1983; Leonard Silk; "Andropov's Economic Dilenma"; The New York-Times Magazine, October 9; 1983. 


\section{The Carl Beck Papers Recent Publications}

\#803 Lars Lih, The Sowing Committees of 1920. \$5.00.

\#802 Larry Holmes, For the Revolution Redeemed: The Workers

Opposition in the Bolshevik Party, 1919-1921. \$5.00.

\#801 James Warhola, Soviet Ethnic Relations and the Fall of Nikolai Podgorny. \$4.50.

\#708 Marie Neudorfl, Tomas Masaryk's Understanding of Democracy Before 1914. \$5.50.

\#707 Joze Mencinger, The Yugoslav Economy: Systemic Changes, 1945-1986. \$4.50.

\#706 Jonathan Harris, Ligachev on Glasnost and Perestroika, \$5.00.

\#705 Barnabas Racz, The Hungarian Parliament in Transition:

Procedure and Politics. $\$ 5.00$.

\#704 Jim Seroka, Change and Reform of the League of Communists in Yugoslavia. \$5.50.

\#701 Albert Resis, Stalin, the Politburo, and the Onset of the Cold War, 1945-1946. $\$ 5.00$.

Please write for a complete list of titles in the series.

Carl Beck Papers

Center for Russian and East European Studies

University of Pittsburgh

4G-12 Forbes Quadrangle

Pittsburgh, PA 15260

(412)648-7407 